\title{
Emotional burnout syndrome in primary specialization doctors
}

V.V. Yekhalov, orcid: 0000-0001-5373-3820, e-mail: sesualiy@gmail.com

O.V. Kravets, orcid: 0000-0003-1340-3290, e-mail: 535951@ukr.net V.P. Stus, orcid: 0000-0002-4539-8126, e-mail: viktor.stus@gmail.com

M.M. Moiseienko, orcid: 0000-0002-5236-4864, e-mail: niknikmoiseenko@gmail.com

D.M. Stanin, orcid: 0000-0001-6510-5282, e-mail: sdm5279@i.ua

D.A. Krishtafor, orcid: 0000-0003-0942-4099, e-mail: shredderine@gmail.com

Dnipro State Medical University

\section{Keywords:}

medical interns, education, emotional burnout, prophylaxis

\section{For citation:}

ДСТУ 8302 2015:

Yekhalov V.V., Kravets O.V., Stus V.P., Moiseienko N.N., Stanin D.M., Krishtafor D.A. Emotional burnout syndrome in primary specialization doctors. Урологія. 2021. Т. 25, № 2. С. 148-148. DOI: $10.26641 / 2307$ 5279.25.2.2021.238243.

APA:

Yekhalov, V.V., Kravets, O.V., Stus, V.P., Moiseienko, N.N., Stanin, D.M., \& Krishtafor, D.A. (2021). Emotional burnout syndrome in primary specialization doctors. Urologiya, 25(2), 148-148. DOI: $10.26641 / 2307-$ 5279.25.2.2021.238243.

\section{SUMMARY}

We conducted an anonymous survey of 140 medical interns at the end of the 2nd year of study in specialties leading in emotional burnout. The results obtained indicate the beginning of the syndrome formation even at the undergraduate level of education, with significant deterioration during the course of primary specialization. Prevention of burnout syndrome should begin with its diagnosis, as well as assessment of the presence of depression, situational and personal anxiety at the early stages of medical education.
«Not a single specialty brings so many moral experiences sometimes as a medical». A.P. Chekhov, "Note book\#1" (1891-1904).

\section{INTRODUCTION \\ Вступ}

According to the WHO definition, emotional burnout syndrome (EBS) is a physical, emotional or motivational exhaustion, which is regarded as a stress response to long-term work and emotional demands arising from a person's excessive dedication to their work with simultaneous neglecting of family life or leisure. According to the International Disease Classification of $10^{\text {th }}$ revision, this condition belongs to the topic "Stress associated with the difficulties of maintaining a normal lifestyle" [1, 2].

It is known that, to a great extent, EBS manifests in representatives of social professions, as a result of intense and prolonged stress at work, and can be 
considered as a state of emotional exhaustion, depersonalization and a decrease in personal achievements. In $96 \%$ of EBS cases, asthenic symptoms are noted, manifesting in increased fatigue, irritability, and decreased performance [3]. Over time, most doctors develop psychosomatic disorders, anxiety levels increase, and the tendency to depression and the use of medications and alcohol to correct emotional stress can lead to addictive behavior [4].

Background. Burnout in doctors is a new problem for the health care system. Literature data on this issue are somewhat contradictory. A number of authors report that the highest percentage of burnout is observed by doctors of the intensive care and emergency departments (55\%), followed by anesthesiologists (50\%) [3, 4, 5, 6, 7]. According to other local and foreign researchers data, family doctors have one of the highest levels of professional burnout among medical workers [8]. Burnout, physical and mental exhaustion occurs in workers in a stressful environment, diagnosed in $50 \%$ of all health workers and $63 \%$ of family doctors in the United States, and this figure is progressively increasing. Even when working in satisfactory conditions, up to $40 \%$ of doctors report having burnout symptoms [9, 10]. In the Dnieper region of Ukraine, a high degree of burnout was diagnosed in $40 \%$ of family doctors [11], and in Uzhgorod and Kramatorsk - more than $80 \%$ [1, 12]. A number of literary sources report the leading position of urologists in this area [13, 14, 15].

C. Peckham survey (2017) included questions on how happy doctors were at work and out of it. It was found that the specialties, where more than $70 \%$ of representatives feel happy outside of working hours, include family medicine doctors and, oddly enough, intensive care doctors, probably because only $28 \%$ of intensive care doctors felt happy at their workplace. During non-working hours, most of the happy respondents were noted among urologists (76\%), but at the same time, only $31 \%$ of urologists were feeling happy at work [16].

Study objective: to study the EBS severity in medical interns of specialties leading in the EBS development during clinical activities; to outline the ways of effective diagnosis and prevention of professional burnout at the stage of primary specialization.

\section{MATERIALS AND METHODS Матеріали і методи дослідження}

We analyzed 140 anonymous survey results of interns at the end of the 2nd year of study in specialties leading in the risk of EBS developing: anesthesiology, urology and general practice - family medicine. A survey was carried out according to the V.V. Boyko method, with 84 "yes or no" questions. The components of the syndrome were determined: the indicator of each symptom severity was assessed as an unformed symptom with 9 or less total points, as forming - with 10-15 points and formed - with 16 or more points $[17,18]$.

\section{RESULTS AND DISCUSSION Результати та їх обговорення}

The learning process also bears the potential danger of EBS developing [17, 19]. This process is activated with the training continuation: the degree of its severity in all indicators is greater in the clinical than in the preclinical period [20]. According to I.A. Guido et al. (2012), a high level of work stress is observed in $48,65 \%$ of interns [21]. Secondary specialization physicians who studied on the job to obtain a family medicine diploma were 3.7 times more likely to be burned out than physicians in formal residency [22] (tabl. 1).

The highest percentage of the formation degree in all three components was shown by family

TABLE 1. The degree of the EBS components formation in interns of different specialties

\begin{tabular}{lcccc}
\hline \multirow{2}{*}{ EBS components } & Specialty & \multicolumn{3}{c}{ Formation degree } \\
& Unformed & Forming & Formed \\
\hline Strain & Anesthesiology & $26,3 \%$ & $63,2 \%$ & $10,5 \%$ \\
& General practice - family medicine & $45,6 \%$ & $24,1 \%$ & $30,3 \%$ \\
Resistance & Urology & $89,9 \%$ & - & $11,1 \%$ \\
& Anesthesiology & $21,0 \%$ & $68,5 \%$ & $10,5 \%$ \\
& General practice - family medicine & $39,6 \%$ & $22,1 \%$ & $38,3 \%$ \\
Exhaustion & Urology & $66,7 \%$ & $22,2 \%$ & $11,1 \%$ \\
& Anesthesiology & $78,9 \%$ & $15,8 \%$ & $5,3 \%$ \\
& General practice - family medicine & $51,5 \%$ & $32,1 \%$ & $16,4 \%$ \\
& Urology & $66,7 \%$ & $33,3 \%$ & - \\
\hline
\end{tabular}


medicine interns with the dominant signs of "experiencing traumatic circumstances", "anxiety and depression" and "inadequate selective emotional response". All indicators were $10-15 \%$ higher than those of the same respondents at the beginning of the internship. Among anesthesiology interns, attention is drawn to the formed "Strain" and "Resistance" indicators being not so high as in family doctors; however, there are high levels of emerging emotional burnout, which, similar to general practice interns, also significantly exceed the initial levels, observed at the beginning of primary specialization, and with the predominance of the same symptoms [17].

Urology interns showed $11.1 \%$ of the formed "Strain" and "Resistance" components, and "Exhaustion" was not revealed at all. The emerging components with dominant "anxiety and depression" and "emotional and moral disorientation" did not exceed the levels of respondents from other specialties.

As we can see, the process of the emotional burnout formation of doctors begins at the stage of undergraduate training and progresses during the primary specialization. The reasons for spread of the syndrome is an increase in the emotional and physical stress of doctors in order to fulfill their professional duties. It should be noted that emotional burnout is largely formed not at the stages of training, but during practical work [17].

It should be noted that a rapid scientific and technological progress, the reverse side of which is constant tension, stress, overload, lack of time, over awareness and other undesirable incidents, along with the prevailing unfavorable socio-economic factors, the severity of which in our country is increasing every year, are accompanied by growth neurotization and psychopathization of the population, and as a whole makes society more aggressive [23]. The specialist is dissatisfied with his professional qualities, the inadequacy of the material reward for the efforts made, the impoverishment of communication culture in population, humiliation of the dignity of the doctor's profession, which is artificially amplified by the media and populist leadership decisions, with an increased workload on the doctor in comparison with that in recent times. This condition quite often leads to physical sickness [4], decreased immunity. That is, urgent preventive measures are needed.

Three groups of factors were identified that influence the occurrence and development of professional burnout in doctors: individual-personal (use of non-constructive coping strategies, high anxiety, emotional instability, depression, aggressiveness); socio-psychological (disturbed socio- psychological climate inside the team) and professional and organizational (high tension at work, low self-esteem for the quality of work, professional stress, difficulties in professional development and selfimprovement). Comprehensive measures for the prevention of professional burnout syndrome in doctors should include professional-organizational, social and individual-psychological areas of work [3, 17].

Prevention of burnout syndrome should begin with its diagnosis, as well as assessment of the presence of depression, situational and personal anxiety [5]. The task of preventive measures is to reduce the likelihood of developing the prerequisites and manifestations of EBS in doctors. In accordance with the selected factors, the work should be carried out in three directions: professional-organizational, social and individual-psychological. As a part of preventive measures at the professional and organizational level, systematic preventive medical examinations could be proposed, a rational mode of working and rest, the work of a psychological relief and relaxation room, a variety of work functions possible within the specialty, etc. [5]. To a large extent, the success of educational programs, especially training programs, is due to the fact that people who come to these groups are already focused on personal changes and on the perception of new things. Teaching people new behavior is realistic only if they want to change. The question is how to induce change in those who are not inclined to do so $[24,25]$. Persons who are to be assigned to specialties that are leading in terms of the risk of developing EBS must first undergo a consultation with a psychologist in order to determine their professional suitability.

\section{CONCLUSIONS Висновки}

1. Emotional burnout in doctors begins to form at the stage of undergraduate education.

2. The greatest intensification of the syndrome occurs not at the stages of training, but during the period of practical activity of family doctors.

3. When individual is distributing to specialties that are leading in the EBS prevalence, they must be consulted by a psychologist in the subject of the professional suitability.

4. Preventive measures should be carried out even at the undergraduate level of medical education.

\section{ІНФОРМАЦІЯ ПРО КОНФЛІКТ ІНТЕРЕСІВ Conflict of interest}

The authors declare that they have no conflicts of interest or their own financial interests in the preparation of this article. 


\section{СПИСОК ЛІТЕРАТУРИ References}

1. Ровенська В.В., Саржевська Є.О. Особливості розвитку та проявів синдрому емоційного вигорання у лікарів. Економічний вісник Донбасу. 2020. № 1(59). C. 123-129. Doi: 10.12958/18173772-2020-1(59)-123-129.

2. Малец Л. Внимание: «выгорание». Персонал. 2000. № 2. С. 99-102.

3. Корехова М.В., Соловьев А.Г., Киров М.Ю., Новикова И.А. Психологические факторы профессионального выгорания врачей анестезиологов-реаниматологов. Клиническая и специальная психология. 2019. Т. 8, № 2. С. 16-37. Doi: 10.17759/ psyclin.2019080202.

4. Васильев В.Ю., Пушкаренко И.А. Причины развития «эмоционального выгорания» у анестезиологов-реаниматологов. Общая реаниматология. 2011. T. VII, № 2. C. 66-70. Doi: 10.15360/ 1813-9779-2011-2-66.

5. Синбухова Е.В., Лубнин А.Ю., Попугаев К.А. Эмоциональное выгорание в анестезиологииреаниматологии. Russian Sklifosovsky Journal of Emergency Medical Care. 2019. № 8(2). C. 186-193. Doi: 10.23934/2223-9022-2019-8-2-186-193.

6. Wang L., Yang H. A study on the status and influence factor of the job burnout of anesthesiologists. Global Journal of Public Health Medicine. 2016. Vol. 2(3). P. 9-17. Doi: 10.14725/ gjph.v2n3a1526.

7. Khan F.A., Shamim M.H., Ali L., Taqi A. Evaluation of Job Stress and Burnout Among Anesthesiologists Working in Academic Institutions in 2 Major Cities in Pakistan. Anesthesia \& Analgesia. 2019. Vol. 128(4). P. 789-795. Doi: 10.1213/ ANE.0000000000004046.

8. Lawrence Ng Chee Lian. Burnout in Primary Care Physicians and Interventions - An EvidenceBased Review. The Singapore Family Physician. 2016. Vol. 42(1). P. 6-12.

9. Puffer J.C., Clifton Knight H.C., O’Neill T.R. et al. Prevalence of Burnout in Board Certified Family Physicians. Journal of the American Board of Family Medicine. 2017. Vol. 30(2). P. 125-126. Doi: 10.3122/jabfm.2017.02.160295.

10. Family Physician Burnout, Well-Being, and Professional Satisfaction (Position Paper). URL: https://www.aafp.org/about/policies/all/familyphysician-burnout.html.

11. Vysochina I.L., Kramarchuk V.V. Professional burnout syndrome among family doctors of Dnipropetrovsk region. In: Modern methods of diagnostics and treatment: experience of EU countries (27-28 december). Lublin, 2019. P. 206-208.
12. Савка Ю.М., Сливка Я.Іे., Поляк-Митровка İ.İ. та ін. Синдром професійного вигорання у медичних працівників м. Ужгород. Проблеми клінічної педіатрії. 2018. № 1. С. 66-72.

13. Живов А.В. Выгорание начинается с неадекватной самооценки и в итоге приводит к обману ожиданий других, в том числе и пациентов. Общество, 27 октября 2020, 16:36. URL: https:// newizv.ru/news/society/27-10-2020/razberites-v-sebekak-vracham-izbezhat-professionalnogo-vygoraniya.

14. Евдокимов В.И., Есауленко И.Э., Губин А.И., Попов В.И. Оценка профессионального выгорания у медицинских работников: методические рекомендации. Воронеж-СПб.: Политехника-сервис, 2009. $82 \mathrm{c.}$

15. Самохвалов А., Крылов Н., Вычужанин Д. Синдром эмоционального выгорания у врачей (сколько мне осталось?). Врач. 2017. № 9. С. 2-5.

16. Peckham C. Medscape Lifestyle Report 2017: Race and Ethnicity, Bias and Burnout. Medscape, Jan. 11. URL: http://www.medscape.com/features/ slideshow/lifestyle/2017/overview.

17. Схалов В. В., Кравець О.В., Криштафор Д.А., Станін Д.М., Хоботова Н.В. Синдром емоційного вигорання у медичній післядипломній освіті. Новини медицини та фармації. 2021. № 4. С. 13.

18. Райгородский Д.Ю. Практическая психодиагностика. Методы и тесты. Самара: Бахрах-М, 2015. C. 341-349.

19. Беззубцева Н.О., Петрова И.В. Синдром эмоционального выгорания у студентов ВУЗа. Материалы XI Международной студенческой научной конференции «Студенческий научный форум», 2019. URL: https://scienceforum.ru/2019/ article/2018011149.

20. Хайрушева Д.А., Белтенова А.Г. Проблема профессионального выгорания в деятельности медицинских работников (обзор). Вестник АГИУВ. 2017. № 3. С. 77-85.

21. Guido L.A., Goulart C. T., da Silva R. M. et al. Stress and burnout among multidisciplinary residents. Revista Latino-Americana de Enfermagem. 2012. Vol. 20, No. 6. P. 1064-1071.

22. Charoentanyarak A., Anothaisintawee T., Kanhasing R. et al. Prevalence of Burnout and Associated Factors Among Family Medicine Residency in Thailand. Journal of Medical Education and Curricular Development. 2020. Vol. 7. Doi: $10.1177 / 2382120520944920$.

23. Усенко Л.В., Кобеляцкий Ю.Ю., Клопоцкая Н.Г., Царев А.В., Усенко А.А., Оленюк Д.В. Конфликтные ситуации в медицинской практике: этические и правовые аспекты. Медицина невідкладних станів. 2020. Т. 16, № 1. С. 115-119. Doi: 10.22141/2224-0586.16.1.2020.196939. 
24. Yekhalov V.V., Kravets O.V., Krishtafor D.A. Psychological Features of the Modern Intern. The world of science and innovation. Abstracts of the 6th International scientific and practical conference. Cognum Publishing House. London, United Kingdom, 2021. P. 304-311. URL: https://sci-conf.com.ua/ vi-mezhdunarodnaya-nauchno-prakticheskayakonferentsiya-the-world-of-science-and-innovation14-16-yanvarya-2021-goda-london-velikobritaniyaarhiv.

25. Ekhalov V.V., Kravets O.V., Stus V.P., Moiseenko M.M., Barannik S.I. Socio-psychological image of the modern intern (educational and social research). Урологія. 2021. Т. 25, № 1. C. 71-80. Doi: 10.26641/2307-5279.25.1.2021.231404.

\section{REFERENCES \\ Список літератури}

1. Wang, L., \& Yang, H. (2016). A study on the status and influence factor of the job burnout of anesthesiologists. Global Journal of Public Health Medicine, 2(3), 9-17.

2. Khan, F.A., \& Shamim, M.H. (2019). Evaluation of Job Stress and Burnout Among Anesthesiologists Working in Academic Institutions in 2 Major Cities in Pakistan. Anesthesia \& Analgesia, 128(4), 789-795.

\section{PEФEPAT}

Синдром емоційного вигорання у лікарів первинної спеціалізації

\author{
В.В. Ехалов. О.В. Кравець, \\ В.П. Стусь, М.М. Моiсеєнко, \\ Д.М. Станін, Д.А. Кріштафор
}

Було проведено анонімне анкетування 140 інтернів наприкінці 2-го року навчання за спеціальностями, які лідирують за ступенем поширеності емоційного вигорання лікарів. Отримані результати свідчать про початок формування синдрому ще на додипломному етапі навчання, та ознаки якого за час проходження первинної спеціалізації значно прогресують. Профілактика синдрому вигорання повинна починатися з його діагностики, а також оцінки наявності депресії, ситуативної та особистісної тривожності на ранніх етапах медичної освіти.

Ключові слова: інтерни, навчання, емоційне вигорання, профілактика.
3. Lawrence Ng Chee Lian. (2016). Burnout in Primary Care Physicians and Interventions - An Evidence-Based Review. The Singapore Family Physician, 42(1), 6-12.

4. Puffer, J.C., \& Knight, H.C. (2017). Prevalence of Burnout in Board Certified Family Physicians. Journal of the American Board of Family Medicine, 30, 2, 125-126.

5. Guido, L.A., \& Goulart, C. T. (2012). Stress and burnout among multidisciplinary residents. Revista Latino-Americana de Enfermagem, 20, 6. 1064-1071.

6. Charoentanyarak, A., \& Anothaisintawee, T. (2020). Prevalence of Burnout and Associated Factors Among Family Medicine Residency in Thailand. Journal of Medical Education and Curricular Development, 7. Doi: 10.1177/ 2382120520944920.

7. Yekhalov V.V., Kravets O.V., Krishtafor D.A. (2021). Psychological Features of the Modern Intern. The world of science and innovation. Abstracts of the 6th International scientific and practical conference. Cognum Publishing House. London, United Kingdom.

8. Ekhalov, V.V., Kravets, O.V., Stus, V.P., Moiseenko, M.M., \& Barannik, S.I. (2021). Sociopsychological image of the modern intern (educational and social research). Urologiya, 25(1), 71-80. Doi: 10.26641/2307-5279.25.1. 2021.231404.

\section{PЕФЕРАТ}

Синдром эмоционального выгорания у врачей первичной специализации

\author{
В.В. Ехалов. О.В. Кравец, \\ В.П. Стусь, Н.Н. Моисеенко, \\ Д.М. Станин, Д.А. Криштафор
}

Было проведено анонимное анкетирование 140 интернов в конце 2-го года обучения по специальностям, которые лидируют по степени распространенности эмоционального выгорания врачей. Полученные результаты свидетельствуют о начале формирования синдрома еще на додипломном уровне обучения, признаки которого за время прохождения первичной специализации значительно прогрессируют. Профилактика синдрома выгорания должна начинаться с его диагностики, а также оценки наличия депрессии, ситуативной и личностной тревожности на ранних этапах медицинского образования.

Ключевые слова: интерны, обучение, эмоциональное выгорание, профилактика. 